\title{
Peranan Media Sosial dan Harga Terhadap Keputusan Pembelian Jasa Rekaman di Demores Rumah Musik
}

\author{
I Made Wira Bimantara \\ Program Studi Manajemen \\ Universitas Pendidikan Ganesha \\ Singaraja. Indonesia \\ e-mail: imadewirabimantara30@undiksha.ac.id ${ }^{* 1}, \underline{k r i s n a . h e r y a n d a @ u n d i k s h a . a c . i d ~}^{2}$
}

Pengutipan:

Bimantara, I. M. W. \& Heryanda, K. K. (2021). Peranan Media Sosial dan Harga Terhadap Keputusan Pembelian Jasa Rekaman di Demores Rumah Musik. Jurnal Pendidikan

Ekonomi

Undiksha, 13(1), 108-116

http://dx.doi.org/1 0.23887/ijpe.v13i 1.32312

\begin{abstract}
Abstrak
Riwayat Artike

Tanggal diajukan:

17 Februari 2021

Tanggal diterima : 3 Mei 2021

Tanggal dipublikasikan: 25 Juni 2021

Penelitian ini bertujuan untuk menguji (1) pengaruh simultan media sosial dan harga terhadap keputusan pembelian, (2) pengaruh parsial media sosial terhadap keputusan pembelian, dan (3) pengaruh parsial harga terhadap keputusan pembelian jasa rekaman di Demores Rumah Musik. Desain penelitian yang digunakan adalah desain penelitian kuantitatif kausal. Data dikumpulkan dengan menggunakan instrument berupa kuesioner yang memiliki total 13 pernyataan, yang kemudian dianalisis dengan menggunakan regresi berganda dengan uji asumsi klasik. Sampel dalam penelitian ini yaitu konsumen dari Demores Rumah Musik yang pernah menggunakan jasanya lebih dari 2 kali, pernah melakukan rekaman selain di Demores Rumah Musik dengan melibatkan 54 responden. Hasil penelitian ini menunjukkan bahwa (1) media sosial dan harga berpengaruh signifikan terhadap keputusan pembelian, (2) media sosial tidak berpengaruh terhadap keputusan pembelian, dan (3) harga berpengaruh positif dan signifikan terhadap keputusan pembelian jasa rekaman di Demores Rumah Musik.
\end{abstract}

Kata kunci: harga; keputusan pembelian; media sosial

Abstract
This study aimed to examine (1) the simultaneous social media and price on
purchasing decisions, (2) the partial effect of social media on purchasing
decisions, and (3) the partial effect of price on recording service at Demores
Rumah Musik. The research design used was a casual quantitative reseach
design.Data was collected using an instrument in the form of a questionnaire that
had a total of 13 statements, then the data obtained were analyzed using multiple
linear regression analysis. The results of this study indicate that (1) social media
and price have a significant effect on purchasing decisions, (2) social media has a
positive and significant effect on purchasing decisions, and (3) price has a positive
and significant effect on Demores Rumah Musik purchasing decisions.

Keywords: price; purchasing decisions; social media.

\section{PENDAHULUAN}

Tahun 2020 merupakan tahun yang mengkhawatirkan seluruh negara. Di masa pendemi ini, yang disebabkan oleh adanya wabah virus baru yang kini masuk ke Indomesia yang menyebabkan keterbatasan manusia dalam melakukan kegiatan seperti pada umumnya. Akibat penyebaran wabah virus corona yang sangat cepat membuat pemerintah mengeluarkan aturan untuk mengurangi kegiatan keluar rumah agar mencegah persebaran wabah yang semakin meluas dan menggunakan protokol kesehetan seperti menggunakan masker dan saling berjaga jarak (social distancing). Akibat 
wabah tersebut banyak dampak yang masyarakat rasakan. Para karyawan banyak yang mulai dirumahkan akibat wabah tersebut dan segala kegiatan yang membuat keramain seperti acara musik acara lain-lain mulai ditiadakan. Hal ini berdampak ke banyak pihak yang masuk di dalamnya yang membuat hilangnya pendapat mereka seperti vendor event yang harus menjaga usahanya tetap bertahan di dalam masa pendemi ini. Akibat masa pandemi ini maka segala kegiatan bekerja atau belajar dilakukan secara online (work from home) yang di lakukan di rumah masing-masing. Hingga kondisi saat ini, virus corona bukanlah suatu wabah yang bisa diabaikan begitu saja. Jika dilihat dari gejalanya, orang awam akan mengiranya hanya sebatas influenza biasa, tetapi bagi analisis kedokteran virus ini cukup berbahaya dan mematikan

Saat ini di tahun 2020, perkembangan penularan virus ini cukup signifikan karena penyebarannya sudah mendunia dan seluruh negara merasakan dampaknya. Salah satu vendor event di kota Singaraja yaitu Demores Rumah Musik yang sebagai penyedia segala kebutuhan event, dan yang paling diketahui oleh kalangan para musisi yaitu tepat untuk rekaman atau recording. Akibat dampak dari pandemi pada saat ini Gde Kurniawan selaku pendiri usaha dan penulis lagu tersebut tetap percaya diri untuk menekan laju pertumbuhan wabah yang sunyi ini dengan memanfaatkan media social sebagai media untuk promosi yang efektif pada saat ini. Dengan merangkul para musisi yang ada di daerah ini Demores Rumah Musik membuat sebuah acara untuk bisa tetap menyalurkan seninya terutama di bidang musik tetapi dengan tetap menggikuti protokol kesehatan dari pemerintah. Dengan membuat sebuat acara Live on Facebook di sebuah platform Facebook menjadikan sebuah tempat para musisi bebas mengeksperesikan karyanya dan dampaknya mendapat promosi secara tidak langsung agar memperluas area pemasaranya di tengah pandemi. Di tengah pandemi ini antusiasme para musisi untuk mengabadikan karyanya semakin meningkat. Di karenakan berbagai hal yang mendukung datangnya ide seni dalam pembuatan lagu semakin muncul dan juga banyak waktu luang yang di akibat pandemi ini. Dikarenakan alat yang digunakan untuk rekaman itu banyak dan yang mahal dan juga diperlukan skill untuk mengunakan alat rekaman tersebut maka para perkerja seni memerlukan tempat untuk rekaman yang terpercaya. Antusias masyarakat tersubut yang dapat dimanfaatkan agar perusahaan dapat tetap bertahan ditengah pandemi.

Di Singaraja terdapat banyak usaha penyedia jasa rekaman lagu. Persaingan seperti sekarang ini perusahaan dituntut untuk menawarkan produk yang berkualitas dan mempunyai nilai lebih, sehingga tampak berbeda dengan produk pesaing. Hal tersebuat akan membuat respon positif dari pelanggan secara langsung yang nantinya manarik para pelanggan. Demores Rumah Musik tentunya memiliki strategi pemasaran tersendiri yang dinilai memiliki potensi bagi perkembangan usahanya. Perbedaan karakteristik dari bisnis barang dan Jasa, tentunya sangat mempengaruhi penetapan strategi pemasaran perusahaan. Pada perusahaan jasa, output yang dihasilkan memiliki karakteristik tidak berwujud, heterogenitas, tidak dapat dipisahkan, dan tidak tahan lama. Demores Rumah Musik menerapkan berbagai strategi untuk mempengaruhi keputusan konsumen, strategi tersebut di antaranya dengan memberikan harga atau tarif sewa yang kompetitif, menggunakan berbagai macam media komunikasi untuk mempromosikan usahanya, serta lebih meningkatkan kualitas pelayanan terhadap konsumen. Kepuasan yang dirasakan konsumen akan berpengaruh terhadap pemakain kembali jasa rekaman di Demores Rumah Musik. 
Tabel 1. Data Jumlah Pemakai Jasa Demores Setiap Tahun

\begin{tabular}{clcc}
\hline No & & Triwulan & Jumlah \\
\hline 1 & Triwulan I (2019) & 95 \\
2 & Triwulan II (2019) & 80 \\
3 & Triwulan III (2019) & 85 \\
4 & Triwulan IV (2019) & 100 \\
5 & Triwulan I (2020) & 30 \\
6 & Triwulan II (2020) & 15 \\
\hline
\end{tabular}

Berdasarkan tabel 1 terlihat bahwa permintaan dari pelanggan Demores Rumah Musik mengalami fluktuasi, dimana jumlah permintaan mengalami peningkatan dari awal triwulan sampai akhir triwulan di tahun 2019, dan mengalami penurunan di awal triwulan di tahun 2020. Hal ini mengindikasikan dengan adanya penurunan jumlah palanggan yang menggunakan jasa Demores Rumah Musik. Maka dari itu perlu diketahui faktor-faktor yang mempengaruhi keputusan pembelian di Demores Rumah Musik.

Keputusan pembelian menurut Schiffman \& Kanuk (2008) keputusan pembelian yaitu sebagai pemilihan dari dua atau lebih alternative sebagai pilihan keputusan pembelian. Artinya bahwa seseorang sebelum melakukan pembelian tersedia beberapa alternative pilihan, sehingga dia harus memilih salah satu diantaranya. Menurut Kotler \& Amstrong (2012) keputusan pembelian dipengaruhi oleh rangsangan pemasaran yang terdiri dari produk, harga, distribusi, dan promosi. Selanjutnya, promosi adalah salah satu bentuk komunikasi pemasaran yang berusaha menyebarkan informasi, mempengaruhi atau membujuk kemudian mengingatkan pasar sasaran atas perusahaan dan produknya, agar bersedia menerima, membeli, dan setia pada produk atau jasa yang di tawarkan oleh perusahaan atau perseorangan yang bersangkutan

Dalam pemasaran kemudahan akses untuk promosi sangatlah penting maka diperlukan media sosial sebagai sarana media yang tepat (Zarella, 2010). Dengan menggunaan media sosial baik melalui blog, social networking, facebook, Instagram, dan berbagai platform lainnya merupakan langkah strategis dalam memasarkan hasil produk. Disaat masa pendemi ini Demores Rumah Musik melakukan acara live on facebook acara ini dalam rangka mengapresiasi para musisi di Buleleng. Dikarenakan untuk mengurangi wabah Covid-19 banyak acara konser musik yang tidak dapat dilaksanakan di saat masa pendemi ini. Acara tersebut dibuatnya murni tidak ada profit yang diraup oleh Demores Rumah Musik. Namun acara tersebut bertujuan untuk melakukan promosi ke media sosial. Nantinya setiap musisi yang telah ikut acara live tersebut akan memposting di akun sosmed mereka masing-masing. Secara tidak langsung dapat menjalin relasi dan semakin banyak masyarakat mengetahuinya. Hal tersebut juga dapat menekan biaya promosi dibandingkan mebayar iklan yang mengeluarkan cost yang tinggi, dikarenakan media sosial memiliki jangkauan yang lebih luas dan mudah diakses dalam mempromosikan produknya dibandingkan dengan memasarkan secara konvensional (Pane, 2014). Media sosial telah menjadi sarana dan media pada komunikasi bisnis dimana informasi dari produk atau jasa dapat dikirimkan kepada masyarakat, baik itu secara individu, komunitas, jaringan, maupun masyarakat umum.

Seiring dengan perkembangan ilmu pengetahuan dan teknologi informasi para perlaku usaha harus beradaptasi dengan berbagai perkembangan tersebut (Haerisma, 2018). Hal itu akan menyerap tenaga kerja sehingga dapat mengurangi angka pengangguran di Indonesia saat ini. Perkembangan industri di Indonesia yang berbasis teknologi infomasi, saat ini menduduki peringkat ketujuh dari sepuluh jenis usaha yang dapat menyerap tenaga kerja dalam jumlah besar (Sadilah, 2010). 
Karakter masyarakat di Indonesia negara berkembang yang masih susah dalam menerima perkembangan teknologi yang ada, menyebabkan melambatnya pertumbuhan ekonomi pada saat ini. Berbeda dengan negara maju yang lebih cepat memanfaatkan hal tersebut dibandingkan oleh negara-negara berkembang termasuk Indonesia (Ningsih, 2014) berkaitan dengan pertumbuhan perekonomian nasional. Perubahan yang pesat dalam dunia digital dan sumber informasi yang tersedia melalui jaringan komputer dan internet, telah menyebabkan perubahan dalam pemasaran tradisional dan persepsi pelanggan pada pemasaran tradisional. Perusahaan berkomunikasi dengan pelanggan melalui iklan, pemasaran langsung, personal selling, promosi penjualan dan hubungan masyarakat menggunakan media cetak dan elektronik yang disebut di sini sebagai media tradisional (Widyaningrum, 2016). Menurut Creeber \& Martin (2009) New Media atau media online merupakan produk dari komunikasi yang termediasi teknologi yang terdapat bersama dengan komputer digital. Dimana media digital pada saat ini mudah diakses dimana pun seperti smartphone yang samakin mempermudah di hampir segala kegiatan. Sedangkan menurut Lievrouw (2011) media online adalah media yang di dalamnya terdiri dari gabungan berbagai elemen. Artinya, terdapat konvergensi media di dalamnya, dimana perlu adanya gabungan dari bebagai media yang dijadikan satu. Masyarakat menggunakan media sosial sebagai sarana dalam melakukan pembelian. Dimana dalam hal tersebut mempermudah membandingkan harga sebelum melakukan pembelian pada suatu produk barang atau jasa.

Table 2. Data Perbandingan Harga Rekaman Lagu

\begin{tabular}{lll}
\hline No & \multicolumn{1}{c}{ Nama Studio } & \multicolumn{1}{c}{$\begin{array}{c}\text { Harga Rekaman } \\
\text { (Include Mixing \& Mastering) }\end{array}$} \\
\hline 1 & Demores Rumah Musik & Rp. $1.000 .000,00$ \\
2 & Kama Record & Rp. $800.000,00$ \\
3 & D Studio & Rp. 800.000 .00 \\
4 & Bisma Music Studio & Rp. $850.000,00$ \\
\hline
\end{tabular}

Dari tabel di atas menjelaskan bahwa harga jasa rekaman di Demores lebih mahal dibandingan pesaingnya. Salah satu faktor yang mempengaruhi keputusan pembelian adalah harga. Harga seringkali digunakan sebagai indikator nilai bilamana harga tersebut dihubungkan dengan manfaat yang dirasakan atas suatu barang atau jasa. Dengan demikian dapat disimpulkan bahwa pada tingkat harga tertentu, bila manfaat yang dirasakan konsumen meningkat, maka nilainya akan meningkat pula (Tjiptono, 2014). Dalam penentuan nilai suatu barang atau jasa, konsumen membandingkan kemampuan suatu barang atau jasa dalam memenuhi kebutuhannya dengan kemampuan barang atau jasa subtitusi. Harga merupakan salah satu atribut penting yang dievaluasi oleh konsumen sehingga manajer perusahaan perlu benar-benar memahami peran tersebut dalam mempengaruhi sikap konsumen. Harga sebagai atribut dapat diartikan bahwa harga merupakan konsep keanekaragaman yang memiliki arti berbeda bagi tiap konsumen, tergantung karakteristik konsumen, situasi dan produk (Mowen \& Minor, 2002). Dengan kata lain, pada tingkat harga tertentu yang telah dikeluarkan, konsumen dapat merasakan manfaat dari produk yang telah dibelinya. Konsumen akan merasa puas apabila manfaat yang mereka dapatkan sebanding atau bahkan lebih tinggi dari nominal uang yang mereka keluarkan. Pelanggan akan menguji harga secara tidak terbatas (Obsolut) akan tetapi dengan membandingkan beberapa standart harga produk yang sama di tempat lain sebagai pertimbangan untuk melakukan keputusan Variabel Harga secara umum bagi pelanggan yang sensitif harga murah 
merupakan sumber keputusan yang penting karena mereka akan mendapatkan value for money yang tinggi (Irawan, 2002). Untuk industri ritel komponen harga merupakan hal penting dan sangat signifikan pengaruhnya terhadap keputusan pelanggan. Sementara bagi pelanggan yang tidak sensitive faktor harga relatif tidak begitu penting kontribusinya terhadap penciptaan keputusan pelanggan. Faktor harga juga tidak mampu menciptakan keunggulan bersaing dalam keputusan pelanggan, karena kebijaksanaan harga sangat rentan terhadap duplikasi. Hal ini didukung penelitian yang dilakukan Lenzun, J. J., Massie \& Adare (2014) yang menyatakan harga berpengaruh secara signifikan terhadap keputusan pelanggan. Selain itu, dalam penelitian yang dilakukan oleh Jamaludin (2015) menjelaskan bahwa ada hubungan yang signifikan antara harga dengan keputusan pembelian.

Sebagaimana diuraikan sebelumnya, perkembangan pesaing terus mengalami peningkatan sejalan dengan peningkatan antusiasme pelanggan pada saat ini. Meningkatnya kebutuhan tersebut telah menumbuhkan persaingan kompetitif. Pelanggan memiliki banyak pilihan tempat yang dapat digunakan sebagai tempat rekaman. Untuk dapat menjadi yang terdepan, pihak Demores Rumah Musik harus mampu memberikan pelayanan yang optimal sehingga pelanggan merasakan manfaat dari pelayanan tersebut. Keunikan tersendiri dari kualitas pelayanan dan nilai yang diterima akan meningkatkan jumlah pelanggan.

Penelitian ini dilakukan di Demores Rumah Musik yang berlokasi di jalan Yeh Mumbul no. 9 Pantai Penimbangan Barat
Kota Singaraja. Berdasarkan latar belakang tersebut, maka penulis mengangkat judul penelitian "Peranan Media Sosial, Dan Harga Terhadap Keputusan Pembelian Jasa Rekaman Di Demores Rumah Musik".

\section{METODE}

Penelitian ini menggunakan desain kuantitatif kausal. Subjek dalam penelitian ini adalah pelanggan dari rekaman Demores Rumah Musik. Sedangkan subjek dalam penelitian ini adalah media sosial, harga dan keputusan pembelian. Populasi dalam penelitian ini adalah seluruh konsumen dari Demores Rumah Musik. Menurut data konsumen dari tahun 2018-2020 yang menggunakan jasa dari Demores Rumah Musik yaitu sebanyak 157 konsumen. Adapun kriteria responden yang diambil sebagai sampel adalah sebagai berikut.

(1) Konsumen yang mengetahui atau pernah melakukan rekaman lebih dari 2 kali di Demores Rumah Musik

(2) Konsumen pernah melakukan rekaman selain di Demores Rumah Musik.

Metode pengumpulan data yang digunakan untuk memperoleh data yang dibutuhkan adalah kuesioner. Adapun instrumen penelitian yang digunakan adalah uji validitas dan uji reliabilitas. Teknik analisis data yang digunakan yaitu analisis deskriptif; uji asumsi klasik meliputi: uji normalitas, uji multikolinearitas, uji heteroskedastisitas koefisien determinasi $\left(R^{2}\right)$, uji regresi berganda dan uji hipotesis.

\section{HASIL DAN PEMBAHASAN}

Tabel 3. Hasil Uji Validitas

\begin{tabular}{cccc}
\hline Variabel & Koefisien Korelasi & P-value & Keterangan \\
\hline \multirow{2}{*}{ Media Sosial $\left(\mathrm{X}_{1}\right)$} & 0,824 & 0,000 & Valid \\
& 0,851 & 0,000 & Valid \\
& 0,806 & 0,000 & Valid \\
Harga $\left(\mathrm{X}_{2}\right)$ & 0,572 & 0,000 & Valid \\
& 0,843 & 0,000 & Valid \\
Keputusan Pembelian $(\mathrm{Y})$ & 0,860 & 0,000 & Valid \\
& 0,833 & 0,000 & Valid \\
& 0,805 & 0,000 & Valid \\
\hline
\end{tabular}




\begin{tabular}{|c|c|}
\hline $\begin{array}{l}0,764 \\
0,851 \\
0,788 \\
0,796 \\
0,836\end{array}$ & $\begin{array}{l}0,000 \\
0,000 \\
0,000 \\
0,000 \\
0,000\end{array}$ \\
\hline $\begin{array}{l}\text { Uji validitas Menurut Ghozali (2011) } \\
\text { Uji validitas digunakan untuk mengukur } \\
\text { sah atau valid tidaknya suatu variabel } \\
\text { kuesioner. Suatu kuesioner dikatakan } \\
\text { valid jika pernyataan pada kuesioner } \\
\text { mampu mengungkapkan sesuatu yang } \\
\text { akan diukur oleh kuesioner tersebut. } \\
\text { Untuk mengukur valid atau tidaknya } \\
\text { kuesioner dengan melihat koefisien } \\
\text { korelasi. Jika korelasi antara skor masing- } \\
\text { masing item pertanyaan terhadap skor } \\
\text { total signifikan (p<0,05) maka pertanyaan } \\
\text { tersebut dapat dikatakan "Valid" dan } \\
\text { sebaliknya (Ghozali, 2011). Berdasarkan } \\
\text { tabel 3 dapat disimpulkan seluruh } \\
\text { pernyataan instrumen dinyatakan valid }\end{array}$ & $\begin{array}{l}\text { untuk mengukur suatu kuesioner yang } \\
\text { merupakan indikator dari variabel atau } \\
\text { konstruk. Suatu kuesioner dikatakan } \\
\text { reliabel atau handal jika jawaban } \\
\text { seseorang terhadap pernyataan adalah } \\
\text { konsisten atau stabil dari waktu ke waktu. } \\
\text { Pengukuran reliabilitas dapat dilakukan } \\
\text { dengan cara one shot atau pengukuran } \\
\text { sekali saja: pengukurannya hanya sekal } \\
\text { dan kemudian hasilnya dibandingkan } \\
\text { dengan pernyataan lain atau mengukur } \\
\text { korelasi antar jawaban pernyataan. SPSS } \\
\text { memberikan fasilitas untuk mengukur } \\
\text { reliabilitas dengan uji statistik cronbach } \\
\text { Alpha. Suatu variabel dikatakan reliabel } \\
\text { jika memberikan nilai Cronbach Alpha > } \\
0.60 \text {. }\end{array}$ \\
\hline
\end{tabular}

karena koefisien korelasi diatas 0,05.

Uji Reliabilitas Menurut Ghozali (2011) Reliabilitas sebenarnya adalah alat

Tabel 4. Hasil Uji Validitas

\begin{tabular}{cccc}
\hline Variabel & $\begin{array}{c}\text { Koefisien } \\
\text { Reabilitas }(\text { Alpha })\end{array}$ & Standart Alpha & Keterangan \\
\hline Media Sosial $\left(\mathrm{X}_{1}\right)$ & 0,807 & 0,60 & Reliabel \\
Harga $\left(\mathrm{X}_{2}\right)$ & 0,775 & 0,60 & Reliabel \\
Keputusan Pembelian $(\mathrm{Y})$ & 0,893 & 0,60 & Reliabel \\
\hline
\end{tabular}

Berdasarkan hasil uji reliabilitas pada Tabel 4, didapat nilai korelasi Cronbach Alpha pada variabel media sosial $(0,807)$, harga $(0,775)$, dan keputusan pembelian $(0,893)$. Hal tersebut dinyatakan reliabel karena nilai Cronbach Alpha lebih besar dari 0,60. Adapun hasil pengujian yaitu sebagai berikut.

(1) Uji Normalitas

Uji normalitas bertujuan untuk menguji apakah dalam model regresi, variabel pengganggu atau residual memiliki distribusi normal. Dalam penelitian ini uji normalitas dilakukan dengan mengamati penyebaran data pada sumbu diagonal satu grafik (Ghozali, 2011). Ketentuannya adalah sebagai berikut. a. Jika data menyebar disekitar garis diagonal dan mengikuti arah garis diagonal atau grafik,maka model regresi memenuhi asumsi normalitas.

b. Jika data menyebar jauh dari garis diagonal dan atau tidak mengikuti arah garis diagonal atau grafik, maka model regresi tidak memenuhi asumsi normalitas.

Hasil uji menggunakan grafik histogram p-plot, dalam penelitian ini dapat dilihat pada gambar berikut: 


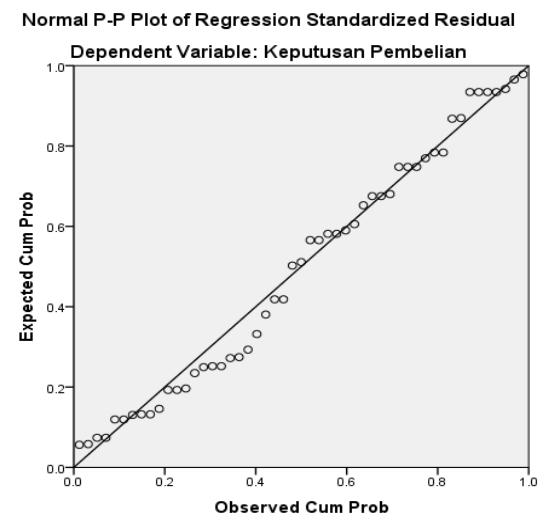

Gambar 1. Hasil Pengujian Normalitas Menggunakan Grafik P-Plot

Berdasarkan hasil pengujian di atas, grafik histogram p-plot menunjukkan bahwa titik-titik yang ada berada disekitar atau tidak jauh dari garis diagonal. Hal ini berarti model regresi tersebut berdistribusi normal.
(2)

\section{Uji Multikolinieritas}

Uji multikolonieritas bertujuan untuk menguji apakah model regresi ditemukan adanya kolerasi antar variabel bebas. Model regresi yang baik seharusnya tidak terjadi kolerasi di antara variabel bebas. Jika variabel independen saling berkolerasi, maka variabel-variabel ini tidak ortogonal. Ortogonal adalah variabel independen yang nilai kolerasi antar sesama variabel independen sama dengan nol (Ghozali, 2011). Untuk mendeteksi ada atau tidaknya multikolonieritas didalam model regresi dengan melihat nilai tolerance dan variance inflation factor (VIF). Nilai cutoff yang umum dipakai untuk menunjukkan adanya multikolonieritas adalah nilai tolerance $<0.10$ atau sama dengan nilai VIP $>10$. Jadi nilai tolerance yang rendah sama dengan nilai VIF tinggi (karena VIF = 1 atau Tolerance).

Tabel 5 Hasil Uji Multikolinieritas

\begin{tabular}{cccc}
\hline \multirow{2}{*}{ Variabel } & \multicolumn{2}{c}{ Collinearity Statistics } & \multirow{2}{*}{ Keterangan } \\
\cline { 2 - 3 } & Tolerance & VIF & Tidak terjadi \\
\hline $\begin{array}{c}\text { Peranan Media } \\
\text { Sosial }\left(\mathrm{X}_{1}\right)\end{array}$ & 0.960 & 1.042 & \\
Harga $\left(\mathrm{X}_{2}\right)$ & 0.960 & 1.042 & $\begin{array}{c}\text { multikolinearitas } \\
\text { Tidak terjadi } \\
\text { multikolinearitas }\end{array}$ \\
\hline
\end{tabular}

Berdasarkan Tabel 4.2 di atas dapat dilihat bahwa seluruh variabel penelitian ini yaitu variabel gaya hidup dan kelompok referenssi memiliki nilai tolerance 0,890 sehingga lebih dari 0,10 dan nilai VIF 1,124 yang berarti dibawah 10 . Sehingga dapat disimpulkan bahwa tidak terjadi multikolenieritas.

(3) Uji Heterokedastisitas

Uji heteroskedastisitas bertujuan untuk menguji apakah dalam model regresi terjadi ketidaksamaan variance dari residual satu pengamantan ke pengamatan yang lain. Model regresi yang baik adalah yang homoskedastisitas atau tidak terjadi heteroskedastisitas (Ghozali, 2011). Untuk mendeteksi ada atau tidaknya heteroskedastisitas dengan cara melihat grafik plot dengan ketentuan sebagai berikut.

a. Jika ada pola tertentu, seperti titik-titik yang ada dan membentuk pola yang teratur (bergelombang, melebar kemudian menyenyempit), maka mengidentifikasikan telah terjadi heteroskedastisitas.

b. Jika tidak ada pola yang jelas, serta titik-titik menyebar di atas dan dibawah angka 0 pada sumbu $\mathrm{Y}$, maka tidak terjadi heteroskedastisitas. 


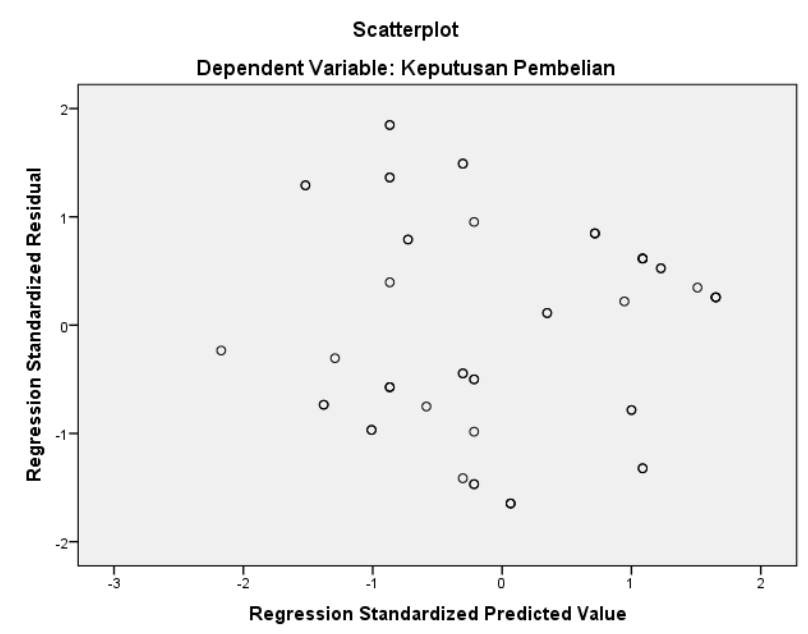

Gambar 2. Hasil Pengujian Heterokedasitas menggunakan Scatterplot

Berdasarkan Gambar 2 menunjukkan bahwa tidak terjadi pola yang jelas serta titik-titik menyebar di atas dan di bawah angka 0 pada sumbu $Y$, sehingga dapat disimpulkan model regresi dalam penelitian ini tidak terjadi heterokedasitas.

Analisis regresi berganda merupakan teknik analisis yang digunakan dalam menganalisa hubungan dan pengaruh satu variabel dan pengaruh satu variabel terikat dengan dua atau lebih variabel bebas (Ghozali, 2011).

Hasil dari analisis regresi berganda pengaruh kualitas produk dan desain produk terhadap keputusan pembelian Sepeda Motor Honda dengan bantuan Program Statistical Package for Social Science (SPSS) 24, maka diperoleh hasil penelitian seperti yang tampak pada Tabel 6 berikut ini.

Tabel 6. Hasil Pengujian Analisis Regresi Linear Berganda

\begin{tabular}{cccc}
\hline Parameter & Koefisien & P-Value & Alpha $(\alpha)$ \\
\hline Ryx $_{1}, \mathrm{X}_{2}$ & 0,541 & 0,05 & 0,05 \\
$\mathrm{R}^{2} \mathrm{yx}_{1}, \mathrm{x}_{2}$ & 0,292 & 0,05 & 0,05 \\
$\mathrm{Pyx}^{2}$ & 0,160 & 0,05 & 0,05 \\
$\mathrm{P}^{2} \mathrm{yx}_{1}$ & 0,025 & 0,05 & 0,05 \\
$\mathrm{Pyx}_{2}$ & 0,500 & 0,05 & 0,05 \\
$\mathrm{P}^{2} \mathrm{yx}_{2}$ & 0,250 & 0,05 & 0,05 \\
$\varepsilon$ & 0,707 & 0,05 & 0,05 \\
\hline
\end{tabular}

Berdasarkan hasil uji regresi berganda pada Tabel 4.3 diperoleh hasil nilai konstanta $(\alpha)$ sebesar 5,079 . Nilai koefisien regresi media sosial $\left(b_{1}\right)$ sebesar 0,609 dan nilai koefisien regresi kelompok referensi $\left(b_{2}\right)$ sebesar 0,313 . Sehingga persamaan regresi diformulasikan sebagai berikut:

$Y=13,042+0,184 X_{1}+0,500 X_{2}+e$

Dari persamaan linier berganda tersebut menunjukkan bahwa:

(1) Konstanta sebesar 13,042 artinya bahwa apabila media sosial $\left(X_{1}\right)$ dan harga $\left(X_{2}\right)$, nilainya sama dengan nol, maka keputusan pembelian (Y) sebesar 13,042.

(2) Nilai koefisien media sosial ( $\left.b_{1}\right)$ sebesar 0,184 berarti bahwa media sosial tidak berpengaruh terhadap keputusan pembelian (Y).
(3) Nilai koefisien harga $\left(b_{2}\right)$ sebesar 0,500 berarti bahwa harga berpengaruh positif terhadap keputusan pembelian (Y). Hal ini mengandung arti bahwa jika harga semakin mendukung maka variabel keputusan pembelian juga akan mengalami kenaikan sebesar 0,500.

\section{SIMPULAN DAN SARAN}

Simpulan

Berdasarkan hasil dan pembahasan yang dilakukan, maka dapat ditarik kesimpulan sebagai berikut.

1. Media sosial dan harga berpengaruh signifikan terhadap keputusan pembelian jasa rekaman di Demores Rumah Musik.

2. Media sosial tidak berpengaruh terhadap keputusan pembelian jasa rekaman di Demores Rumah Musik. 
3. Harga berpengaruh positif dan signifikan terhadap keputusan pembelian jasa rekaman di Demores Rumah Musik.

\section{Saran}

Berdasarkan hasil analisis pembahasan serta beberapa kesimpulan pada penelitian ini, adapun saran-saran yang dapat diberikan melalui hasil penelitian ini agar mendapat hasil yang lebih baik yaitu sebagai berikut.

(1) Bagi peneliti selanjutnya diharapkan dapat mengembangkan penelitian ini dengan menambahkan variabelvariabel lain yang mempengaruhi keputusan pembelian, mengembangkan subjek penelitian dan dapat memperbanyak teori-teori tentang variabel yang digunakan serta dapat menggunakan teknik analisis data yang lain agar dapat menjadi acuan dari penelitian-penelitian selanjutnya dan dapat menambah ilmu pengetahuan khususnya dalam manajemen pemasaran.

(2) Untuk Demores Rumah Musik, diharapkan perusahaan dapat mengelola peran media sosial agar dapat menjadi media promosi yang baik. Selain itu adanya harga yang yang bisa bersaing agar mendapatkan keputusan pembelian dari konsumen

\section{Daftar Pustaka}

Creeber, G., \& Martin, R. (2009). Digital cultures: Understanding New Media. Berkshires- England : Open University Press (McGraw-Hill education).

Ghozali, I. (2011). 'Aplikasi Analisis Multivariate Dengan Program SPSS. Semarang: Universitas Diponegoro.

Haerisma, A. S. (2018). Pengembangan Ekonomi Kreatif Bidang Fashion Melalui Bauran Pemasaran. Jurnal Al-Amwal, 10(1), 91-104.

Irawan, H. (2002). Kepuasan Pelanggan. Jakarta: PT Elex Media Komputindo.

Jamaludin. (2015). Pengaruh Promosi Online dan Presepsi Harga Terhadap Keputusan Pembelian. Jurnal Administasi Bisnis, 21(11).

Kotler, P., \& Amstrong, G. (2012).
Principles of Marketing Edisi 14. England: Pearson Education Limited.

Lenzun, J. J., Massie, J. D., \& Adare, D. (2014). Pengaruh Kualitas Produk, Harga dan Promosi terhadap Kepuasan Pelanggan Kartu Prabayar Telkomsel. Jurnal EMBA, 1(3), 12371245.

Lievrouw, L. (2011). Alternative and Activist New Media. Malden: MAPolity Press.

Mowen, J. C., \& Minor, M. (2002). Perilaku Konsumen.London.

Ningsih, C. (2014). Sinergitas Industri kreatif Berbasis Pariwisata Dengan Strategi Pembangunan Industri Nasional Menuju Globalisasi. Jurnal Manajemen Resort \& Leisure, 11(1), 59-64.

Pane, E. (2014). Tingkat Adopsi Media Sosial Sebagai Sarana Pemasaran Produk Industri Kecil dan Menengah. Jurnal Penelitian Dan Pengembangan Komunikasi Dan Informatika, 5(1), 1-15.

Sadilah, E. (2010). Industri Kreatif Berbasis Ekonomi Kreatif. Jurnal Jantra, 9, 720-728.

Schiffman, L. G., \& Kanuk, L. L. (2008). Perilaku Konsumen. Jakarta: Indeks.

Tjiptono, F. (2014). Pemasaran Jasa Prinsip, Penerapan Dan Penelitian. Yogyakarta: Andi Offset.

Widyaningrum, P. W. (2016). Peran Media Sosial sebagai Strategi Pemasaran pada Sewa Kostum Meiyu Aiko Malang. Jurnal Al Tijarah, 2(2), 230257.

Zarella, D. (2010). The Social Media Marketing Book. USA: Oreilly Media. 